\title{
Modified respiratory quotient to evaluate the environmental impact of Chinese coal combustion
}

\section{Wei Chen}

School of Energy,

Soochow University,

Suzhou, 215006, China

Email: timtamu001@yahoo.com

\section{Yafeng Lei}

General Electrical Company,

Houston 77041, Texas, USA

Email: 172127655@qq.com

\section{Shuanglin Shen}

Department of Mechanical Engineering,

China University of Mining and Technology,

Xuzhou, China

Email: shensln.1@stu.xjtu.edu.cn

\section{Jiafeng Sun}

Department of Thermal and Powering Engineering,

Texas A\&M University,

College Station, TX 77840, USA

Email:1173215171@qq.com

\section{Siva Thanapal}

Department of Mechanical Engineering,

Texas A\&M University,

College Station, TX 77840, USA

Email: Sivsan.siva@gmail.com

\section{Xueliang Fan*}

School of Rail Transportation,

Soochow University,

Suzhou, 215131, China

Email: xlfan@suda.edu.cn

*Corresponding author 


\begin{abstract}
Considering the effect of ash and moisture on $\mathrm{CO}_{2}$ emission during combustion, a modified respiratory quotient $\left(\mathrm{RQ}_{\mathrm{m}}\right)$ was employed to determine the $\mathrm{CO}_{2}$ emission potential of anthracite, bituminous, lignite, and peat in China. It was found that the conventional RQ of different Chinese coals was almost the same (from 0.9 to 1 ), but $R_{\mathrm{m}}$ of coals varies significantly. The low-rank coals such as peat and lignite have significantly high $\mathrm{RQ}_{\mathrm{m}}$ which can go up to 7. The high-rank coals such as anthracite and bituminous coals have $R_{m}$ between 1 and 2. Higher $\mathrm{RQ}_{\mathrm{m}}$ means more $\mathrm{CO}_{2}$ emission since more energy is required to transport or process the low-rank coals. Moreover, correlations between $\mathrm{O} / \mathrm{C}$ and $\mathrm{H} / \mathrm{C}$ ratios of the coals and $\mathrm{RQ}_{\mathrm{m}}$ were also analysed. It was found that low-rank coals such as lignite and peat have higher $\mathrm{H} / \mathrm{C}$ and $\mathrm{O} / \mathrm{C}$ ratios and their $\mathrm{RQ}_{\mathrm{m}}$ are correspondingly higher. [Received: April 2, 2017; Accepted: July 1, 2017]
\end{abstract}

Keywords: respiratory quotient; carbon dioxide; heating value; zero emission; coal.

Reference to this paper should be made as follows: Chen, W., Lei, Y., Shen, S., Sun, J., Thanapal, S. and Fan, X. (2018) 'Modified respiratory quotient to evaluate the environmental impact of Chinese coal combustion', Int. J. Oil, Gas and Coal Technology, Vol. 17, No. 2, pp.238-255.

Biographical notes: Wei Chen is working as an Associated Professor at the School of Energy at Soochow University. He received his PhD in Mechanical Engineering at the Texas A\&M University. His research interests are solid fuel combustion, thermodynamics and enhanced technology of heat and mass transfer.

Yafeng Lei is a Senior Project Engineer of the BEE. He received his $\mathrm{PhD}$ in Mechanical Engineering from the Texas A\&M University. His research interests are heat transfer, combustion and energy efficiency.

Shuanglin Shen is working as an Assistant Professor at the Thermal and Powering Engineering at the China University of Mining and Technology. He received his $\mathrm{PhD}$ in Engineering Thermal Physics at the Xian Jiaotong University. His research interests are fuel cell, heat and mass transfer.

Jiafeng Sun graduated from the Texas A\&M University with Doctoral in Mechanical Engineering. He now works in The DHTE Group LLC as a Project Engineer, mainly responsible for the development of alternative fuel mining trucks. He has published several papers in the area of internal combustion engine, combustion and coal.

Siva Thanapal completed his $\mathrm{PhD}$ in Mechanical Engineering at the Texas A\&M University in March 2014. He worked on different solid fuel [low quality biomass (lignocellulosic and dairy), Texas lignite and sub-bituminous coal (PRB)] thermo-chemical conversion techniques. Currently, he serves as an Environmental Consultant with the Trinity.

Xueliang Fan is working as a Lecturer at the School of Rail Transportation at the Soochow University. He received his $\mathrm{PhD}$ in Engineering Thermal Physics at the University of Science and Technology of China (USTC). His research interests are high efficient utilisation of energy, phase change in thermodynamics and enhanced technology of heat and mass transfer. 


\section{Introduction}

Coal is the most important source of energy in China. Due to the rapid economic growth in China, the dependence on this fossil fuel for power generation keeps growing. The combustion of coals, however, adds in a significant amount of carbon dioxide $\left(\mathrm{CO}_{2}\right.$, a major greenhouse gas contributing to global warming) to the atmosphere per unit of heat energy, more than does the combustion of other fossil fuels (DOE/EIA, 1993). Moreover, coal burning is a major source of atmospheric pollution, with particulates, $\mathrm{SO}_{2}$ and $\mathrm{NO}_{\mathrm{x}}$. According to Energy Information Administration (EIA, 2014), the total $\mathrm{CO}_{2}$ emission of China was around 8,106 million metric tons in 2012. $\mathrm{CO}_{2}$ from the utilisation of coals contributed $80.3 \%$ (6,512 million metric tons) of total emissions (EIA, 2014). Moreover, the world's total coal consumption reached 165 quadrillion BTU in 2015, of which China's share was more than $50 \%$. Also, China contributed $88 \%$ of the growth in world's coal consumption (EIA, 2017). The total $\mathrm{CO}_{2}$ emission of China will keep increasing in the next decades. In China, power generation consumes about $80 \%$ of the coal production. Thus, improving energy conversion efficiency and reducing the pollution from coal combustion would be the first priority for Chinese authorities.

Different methods have been used to evaluate the $\mathrm{CO}_{2}$ emission with regard to the rank of coals. Hong and Slatick (1994) used $\mathrm{CO}_{2}$ emission factor which is defined as pounds of $\mathrm{CO}_{2}$ per million BTU in terms of the energy content of coals to evaluate the emission of different types of coals. Annamalai (2013) and Thanapal et al. (2014) first applied the concept of respiratory quotient (RQ), a term used in the biological literature, to evaluate the rank of fossil and biomass fuels combustion based on $\mathrm{CO}_{2}$ emissions. RQ is defined as the ratio of moles of $\mathrm{CO}_{2}$ produced to moles of stoichiometric oxygen $\left(\mathrm{O}_{2}\right)$ consumed during oxidation reaction (e.g., oxidation of nutrients in the human body) (Thanapal, 2014). RQ enables the estimation of global warming potential (GWP) of different fuels, even new fuels such as torrefied biomass fuels for combustion applications. RQ of the new fuels can be compared to the conventional fossil fuels in order to determine the fuels' emission potential. Thanapal (2014) calculated RQ of various gaseous, liquid and solid fuels. RQ of raw biomass is equal to zero if biomass is considered as carbon neutral fuel. Lower RQ values mean less $\mathrm{CO}_{2}$ emission to atmosphere and less GWP. In order to reduce $\mathrm{CO}_{2}$ emission, more stringent regulations and laws such as carbon tax were levied by national governments and international organisations such as European Union's carbon tax (Annamalai, 2013; Jangam et al., 2011). Utilisations of new combustion technology and renewable energy are encouraged to reduce greenhouse gas emission. Thanapal et al. (2014) found 90:10 blends of coal (RQ of 0.92) and torrefied woody biomass (RQ of 0.82) could reduce the RQ value to 0.84 .

By now, all the RQ values of the fuels were calculated on a dry and ash free basis. In reality, ash and moisture exist in all kinds of fuels, especially solid fuels and the weight percentages vary with fuel types. Lignite coal may contain a high amount of moisture (up to $60 \%$ ) (Gordillo et al., 2009); animal waste such as dairy biomass and feedlot contain more than 15\% ash (Annamalai et al., 1987). High percentages of moisture and ash in fuels lead to significantly low energy density and low furnace energy conversion efficiency. Meanwhile, it increases the emission of $\mathrm{CO}_{2}$ in a unit of ton/GJ. The recent development of hydraulic fracture technology has dramatically increased the production of shale gas or natural gas, a large portion of which are used for power generation in the 
USA. In 2015, natural gas overtook coal as the top source of USA's electric power generation. However, low-ranked coals are still the primary fuel for electricity power generation in China. Currently, the greenhouse gas release regulation is more stringent than ever. A more realistic method to define RQ and its influence on coal ranking are very important to estimate $\mathrm{CO}_{2}$ emission potential. The definition of RQ from the empirical chemical formula (or ultimate analysis) and from exhaust gas analysis is not enough to estimate the $\mathrm{CO}_{2}$ emission of coal combustion since low-ranked coals contain abundant ash and moisture, but RQ does not consider ash and moisture.

In this study, a modified respiratory quotient $\left(\mathrm{RQ}_{\mathrm{m}}\right)$ which considers the contribution of the ash and moisture in combustion was proposed to estimate $\mathrm{CO}_{2}$ emission potential for coals of different ranks such as anthracite, bituminous, lignite, etc. The correlation between fuel heating value and $\mathrm{RQ}_{\mathrm{m}}$ was analysed and established. Moreover, the effect of $\mathrm{O} / \mathrm{C}$ and $\mathrm{H} / \mathrm{C}$ ratios on $\mathrm{RQ}_{\mathrm{m}}$ was studied. $\mathrm{RQ}_{\mathrm{m}}$ combines carbon content and heating values of fuels and is an explicit metric for comparison of GWP among fuels.

\section{Definitions of $R Q$ and $R Q_{m}$}

\subsection{Conventional $R Q$}

The conventional RQ which was used to calculate basal metabolic rate in biology was recently applied to evaluate the $\mathrm{CO}_{2}$ emission potential of four different types of fuels such as biomass fuels and transportation fuels (Annamalai, 2013; Thanapal, 2014). Since empirical chemical formulas of coals are in the form of C-H-N-O-S, the negligible $\mathrm{N}$ from air or fuel is assumed to be converted into NO during combustion and coal combustion is completed in a stoichiometric condition (Thanapal, 2014). According to the definition of RQ, it can be determined from the empirical chemical formula or the ultimate analysis of fuel as shown in equation (1) (Thanapal et al., 2014; Annamalai, 2013).

$$
R Q=\frac{\mathrm{CO}_{2} \text { moles produced }}{\mathrm{O}_{2} \text { moles produced }}=\frac{1}{\left\{1+\left(\frac{H}{4 C}\right)-\left(\frac{O}{2 C}\right)+\frac{S}{C}\right\}}
$$

where $C, H, O$ and $S$ are the numbers of carbon, hydrogen, oxygen and sulphur atoms respectively. According to equation (1), Thanapal et al. (2014) calculated that RQ value is 0.5 for methane (gaseous fuel); 0.67 for methanol (liquid fuel); 0.92 and 0.93 for Wyoming coal and Texas lignite respectively. Based on this definition, hydrogen is considered as a clean fuel since the combustion product is $\mathrm{H}_{2} \mathrm{O}$ with zero RQ value.

Instead of analysing fuel compositions, an alternative method to determine RQ for a fuel based on exhaust gas composition is proposed in equation (2) (Annamalai, 2013; Thanapal et al., 2014).

$$
R Q=\frac{C \mathrm{O}_{2} \text { moles produced }}{\mathrm{O}_{2} \text { moles produced }}=\frac{X_{\mathrm{CO}_{2}, e}\left(\frac{X_{N_{2}, i}}{1-X_{\mathrm{O}_{2}, e}-X_{\mathrm{CO}_{2}, e}}\right)-X_{\mathrm{CO}_{2}, i}}{1-X_{\mathrm{O}_{2}, e}\left(\frac{X_{N_{2}, i}}{1-X_{\mathrm{O}_{2}, e}-X_{\mathrm{CO}_{2}, e}}\right)}
$$


where $X_{N_{2}}, X_{\mathrm{CO}_{2}}$ and $X_{\mathrm{O}_{2}}$ are the mole fractions of $\mathrm{N}_{2}, \mathrm{CO}_{2}$ and $\mathrm{O}_{2}$ which could be either on a dry or a wet basis and the subscripts $i$ and $e$ refer to inlet and exit of combustion chamber respectively.

\subsection{Modified respiratory quotient}

Different from gaseous fuel, the conventional RQ cannot make a distinction for solid fuel combustion since it is calculated based on a dry-and-ash-free basis. The RQ values are similar for different coals and it cannot differentiate the coals' $\mathrm{CO}_{2}$ emission potential. For example, RQ of Wyoming coal and Texas lignite are 0.92 and 0.93 , respectively (Thanapal, 2014). In reality, moisture and ash significantly lower the energy density of coals and hence, power plants need to consume more low-rank coals to maintain the same energy input, which results in extra $\mathrm{CO}_{2}$ emission. The process and transportation of low energy density coals incurs more energy and financial costs (electrical power for grinding, fuel used for collection and transportation and energy for coal ash removal, etc.). Considering the $\mathrm{CO}_{2}$ release from all these processes, the actual RQ value should be even higher. As a result, a $\mathrm{RQ}_{\mathrm{m}}$ considering the energy density of coal was used to estimate $\mathrm{CO}_{2}$ emission from coals of different ranks. In this study, a heating value factor $\left(h_{f}\right)$ defined as the ratio of fuel higher heating value (HHV, as received) to that of natural gas was brought into the conventional RQ equation to describe solid fuel quality as shown in equation (3). Here, $\mathrm{H}_{2} \mathrm{O}$ in the end product gases was assumed to be liquid water and latent heat was released to the environment. Thus, HHV was selected for calculation in equation (3). In this equation, the HHV of natural gas (main composition is $\mathrm{CH}_{4}$ ) is used as a reference for coals of different grades since natural gas is a gaseous fuel and considered to be a more efficient and cleaner fuel to replace coal in power plants to reduce $\mathrm{CO}_{2}$ emission. The modified $\mathrm{RQ}$ is defined as

$$
R Q_{m}=\frac{\mathrm{CO}_{2} \text { moles produced }}{\mathrm{O}_{2} \text { moles produced }}=\frac{h_{f}}{\left\{1+\left(\frac{H}{4 C}\right)-\left(\frac{O}{2 C}\right)+\frac{S}{C}\right\}}
$$

where $h_{f}=\frac{H H V_{\mathrm{CH}_{4}}}{H H V_{\text {fuel }_{\text {(As received })}}}$.

$\mathrm{RQ}_{\mathrm{m}}$ based on exhaust gas composition of an unknown fuel is given as equation (4):

$$
R Q_{m}=\frac{C \mathrm{O}_{2} \text { moles produced }}{O_{2} \text { moles produced }}=h_{f} \frac{X_{\mathrm{CO}_{2}, e}\left(\frac{X_{\mathrm{N}_{2}, i}}{1-X_{O_{2}, e}-X_{\mathrm{CO}_{2}, e}}\right)-X_{\mathrm{CO}_{2}, i}}{1-X_{O_{2}, e}\left(\frac{X_{N_{2}, i}}{1-X_{O_{2}, e}-X_{C O_{2}, e}}\right)} .
$$

\section{Fuel proximate and ultimate analysis}

In this study, four ranks of coals including anthracite, bituminous, lignite and peat were selected for RQ analysis. Each rank of coal includes five samples obtained from different locations. Tables 1 to 4 give the proximate analysis, ultimate analysis and $\mathrm{CO}_{2}$ emission potential of these 20 samples. 


\section{Results and discussions}

\subsection{Fuel properties}

As shown from the ultimate analysis of coals in Table 1 to Table 4, anthracite and bituminous coals contain a large amount of carbon have the least impurities and higher energy density. However, lignite contains more than $30 \%$ ash and moisture and peat has more than $50 \%$ ash and moisture. High amounts of moisture and ash not only reduce the calorific value of coals and the thermal efficiency of power plants but also increase the system maintenance cost. Coals with high amounts of ash and moisture are less suitable for combustion. In addition, more energy is required to process these low-rank coals before combustion which increases of $\mathrm{CO}_{2}$ emission. $\mathrm{CO}_{2}$ emission of these four ranks of coals ranges from 0.075 to 0.095 tons/GJ on a dry and ash-free basis. Among these coals, anthracite has the highest $\mathrm{CO}_{2}$ emission (around 0.095 tons/GJ on dry ash free basis).

\subsection{HHV of coals per unit stoichiometric oxygen}

The heating value of a fuel is defined as the amount of heat released when a unit mass or volume of fuel is burned at stoichiometric conditions. Boie empirical equation for estimating the $\mathrm{HHV}$ of fuels in the form of $\mathrm{C}_{\mathrm{C}} \mathrm{H}_{\mathrm{H}} \mathrm{N}_{\mathrm{N}} \mathrm{O}_{\mathrm{O}} \mathrm{S}_{\mathrm{S}}$ on dry and ash free basis is given in equation (5) (Annamalai et al., 1987):

$$
H H V_{\text {daf }, k J / k m o l e}=422270 N_{C}+117385 N_{H}-177440 N_{O}+87985 N_{N}+335510 N_{S}
$$

where $N_{C}, N_{H}, N_{O}, N_{N}$ and $N_{S}$ are the number of carbon, hydrogen, oxygen, nitrogen and sulphur atoms respectively in the fuel, which can be obtained from the fuel's ultimate analysis. Since coals contain a certain amount of moisture and ash, the HHV of coals would be lower on as-received basis. The $\mathrm{HHV}_{\mathrm{ad}}$ is given in equation (6):

$$
H H V_{a d}=H H V_{d a f} / M_{C_{C} H_{H} N_{N} O_{O} S_{S}} \times\left(1-Y_{A}-Y_{M}\right)
$$

where $M_{C_{C} H_{H} N_{N} O_{O} S_{S}}$ is the molecular weight of fuel, $Y_{A}$ and $Y_{M}$ are the weight percentage of ash and moisture, respectively. To estimate the amount of heat produced from consumption of per unit mass oxygen during the combustion process, $\mathrm{HHV}_{\mathrm{O}_{2}}$ is defined as equation (7) (Thanapal, 2014):

$$
H H V_{O_{2}}=\frac{H H V_{a d}}{W_{O_{2}}}
$$

where $W_{\mathrm{O}_{2}}$ is consumed oxygen weight $(\mathrm{kg})$ per $\mathrm{kg}$ fuel. It is observed from Figure 1 that $\mathrm{HHV}_{\mathrm{O}_{2}}$ is between 13,000 and $14,400 \mathrm{~kJ} / \mathrm{kg} \mathrm{O}_{2}$ for different coals and it increases with the decrease of coal rank. The reason is that with the decrease of coal rank, $\mathrm{O} / \mathrm{C}$ ratio increases and less $\mathrm{O}_{2}$ is required to sustain the combustion to release the same amount of heat from coal. 
Figure 1 Coal $\mathrm{HHV}_{\mathrm{O} 2}$ vs. O/C ratio (see online version for colours)

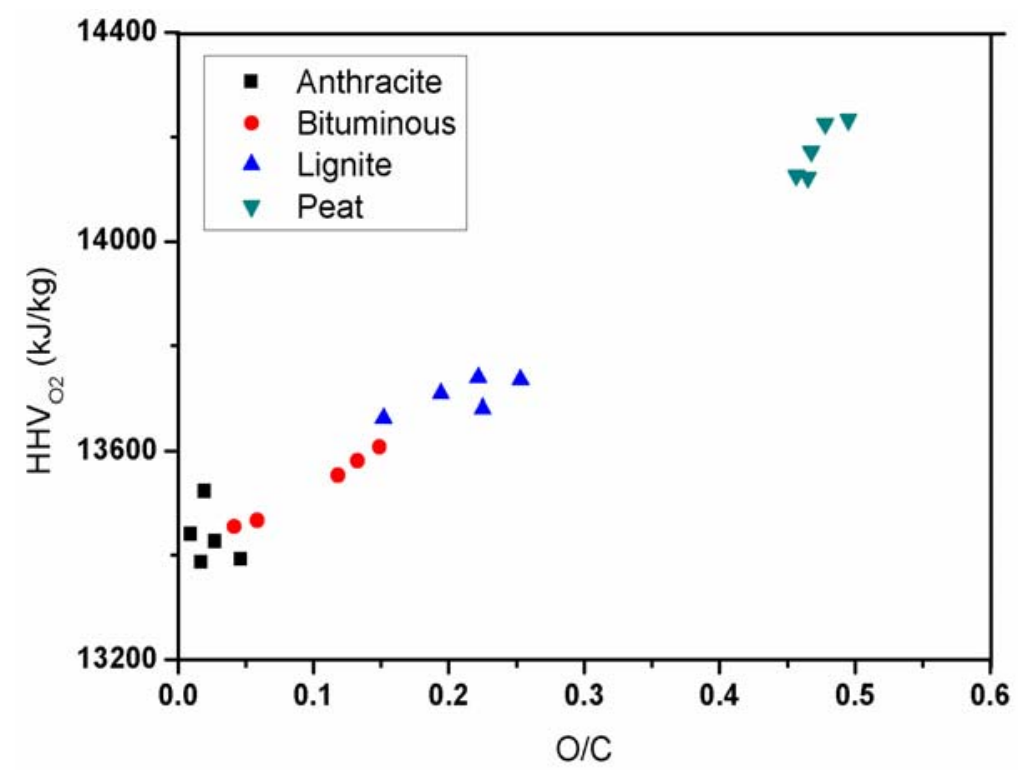

\subsection{Coal $R Q$ and $R Q_{m}$ based on fuel ultimate analysis}

According to equation (1) and equation (3), RQ and $\mathrm{RQ}_{\mathrm{m}}$ of these 20 coals were calculated and are shown in Figure 2. It is found that RQ of methane is 0.5 , which is lower than those of coals ( 0.85 to 1$)$. Also, RQ values do not vary much from anthracite to peat and the values vary from 0.9 to 1 . As a result, the GWP of these coals cannot be distinguished based on conventional RQ values. When ash and moisture were considered in the calculation, $R_{\mathrm{m}_{\mathrm{m}}}$ values of these coals vary significantly. For example, $\mathrm{RQ}_{\mathrm{m}}$ is around 1.5 for anthracite while it rises to 4 for lignite. Moreover, $\mathrm{RQ}_{\mathrm{m}}$ also varies in a certain level for each class of coals, especially for lignite and peat due to the variation of ash and moisture mass percentages.

\section{$4.4 H H V_{a d}$ of coals vs. $R Q_{m}$}

The $\mathrm{HHV}_{\mathrm{ad}}$ of coals to $\mathrm{RQ}_{\mathrm{m}}$ are given in Figure 3. It shows that the heating values of coals decrease with the increase of $\mathrm{RQ}_{\mathrm{m}}$. High-grade coals (e.g., low $\mathrm{RQ}_{\mathrm{m}}$ ) such as anthracite contain more fixed carbon, less ash and less moisture and thus, its energy density is high. For example, the heating value of anthracite coal with $\mathrm{RQ}_{\mathrm{m}}$ of 1.5 is more than $30,000 \mathrm{~kJ} / \mathrm{kg}$. However, it is less than $15,000 \mathrm{~kJ} / \mathrm{kg}$ for peat coal. As a result, coals with lower $R Q_{m}$ are more environmentally friendly due to lower $\mathrm{CO}_{2}$ emissions. 
Table 1 Fuel properties of anthracite

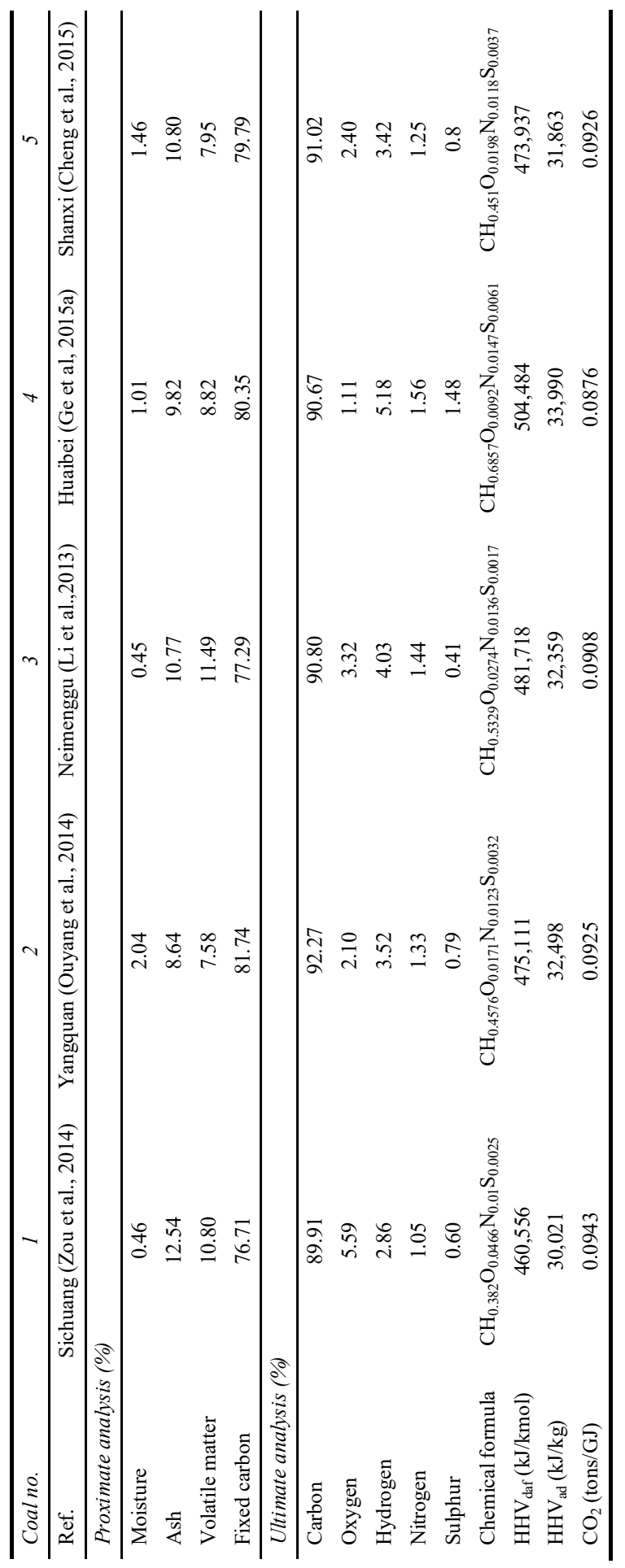


Table 2 Fuel properties of bituminous

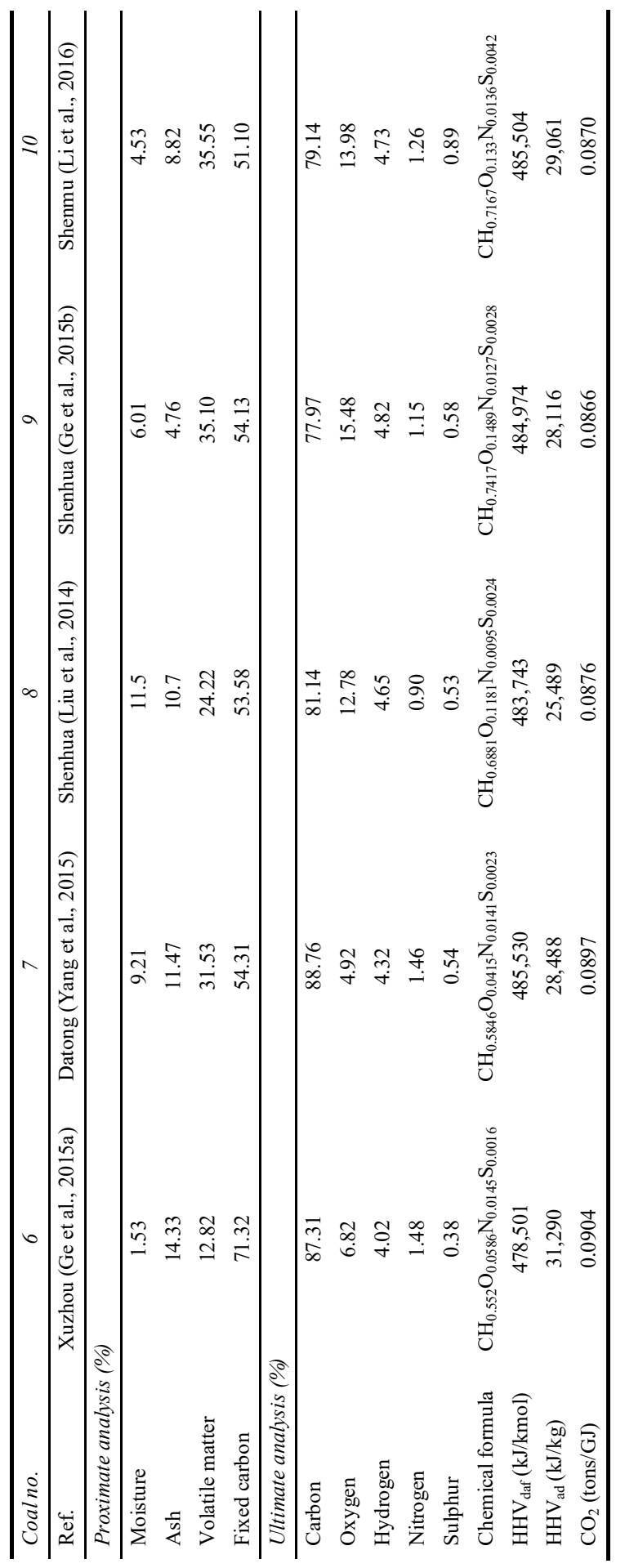


Table 3 Fuel properties of lignite

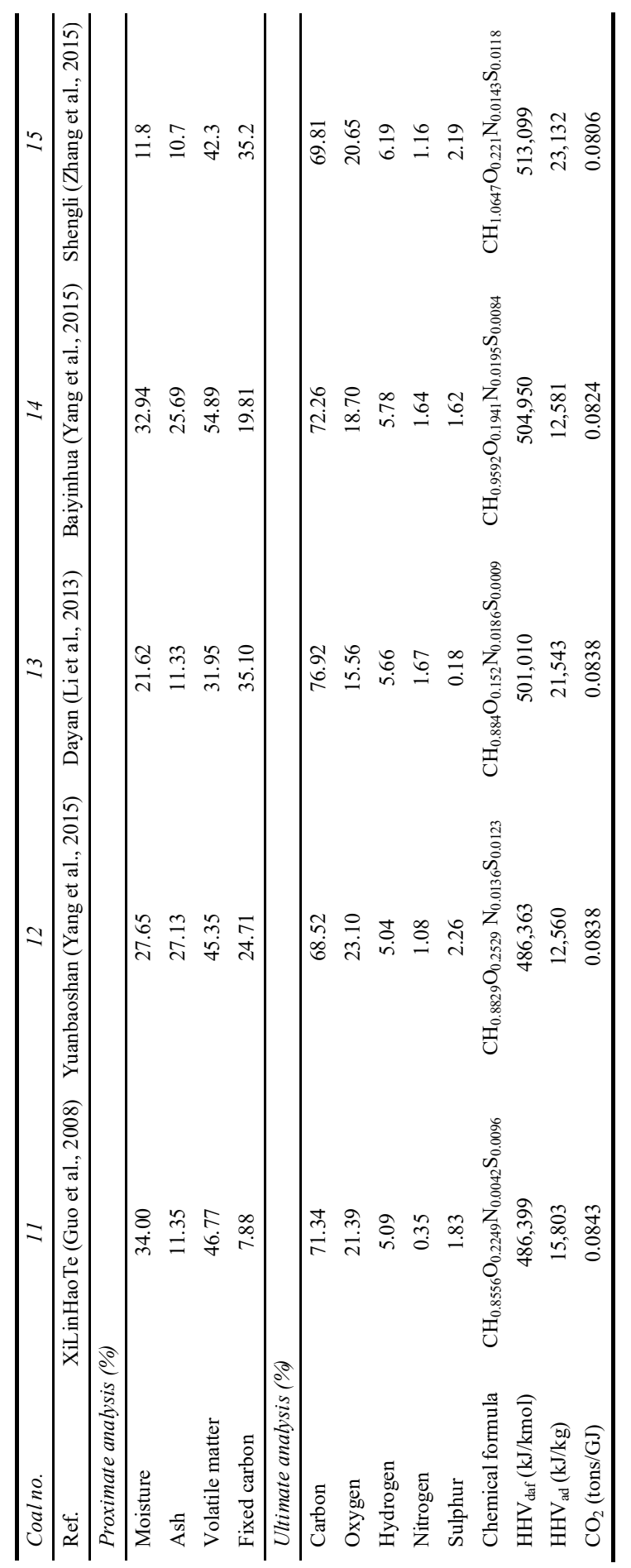


Table 4 Fuel properties of peat

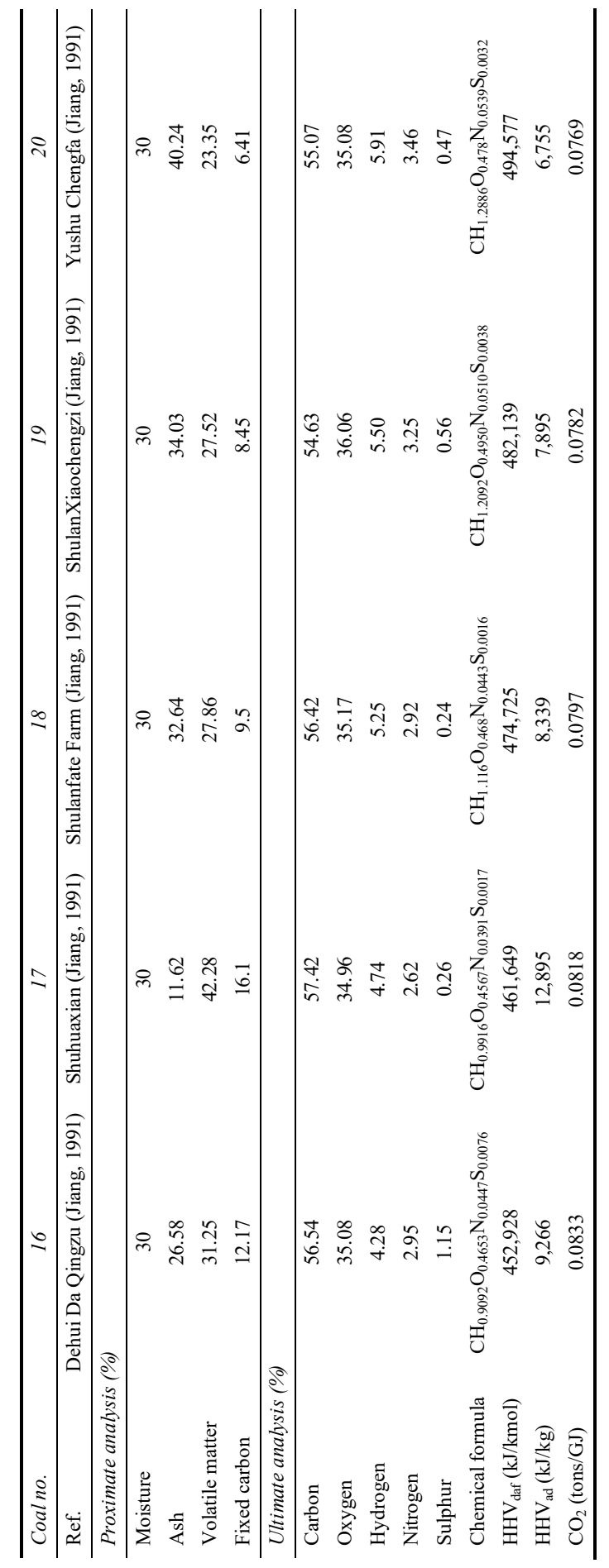


Figure 2 RQ and $\mathrm{RQ}_{\mathrm{m}}$ of the four ranks of coals (see online version for colours)

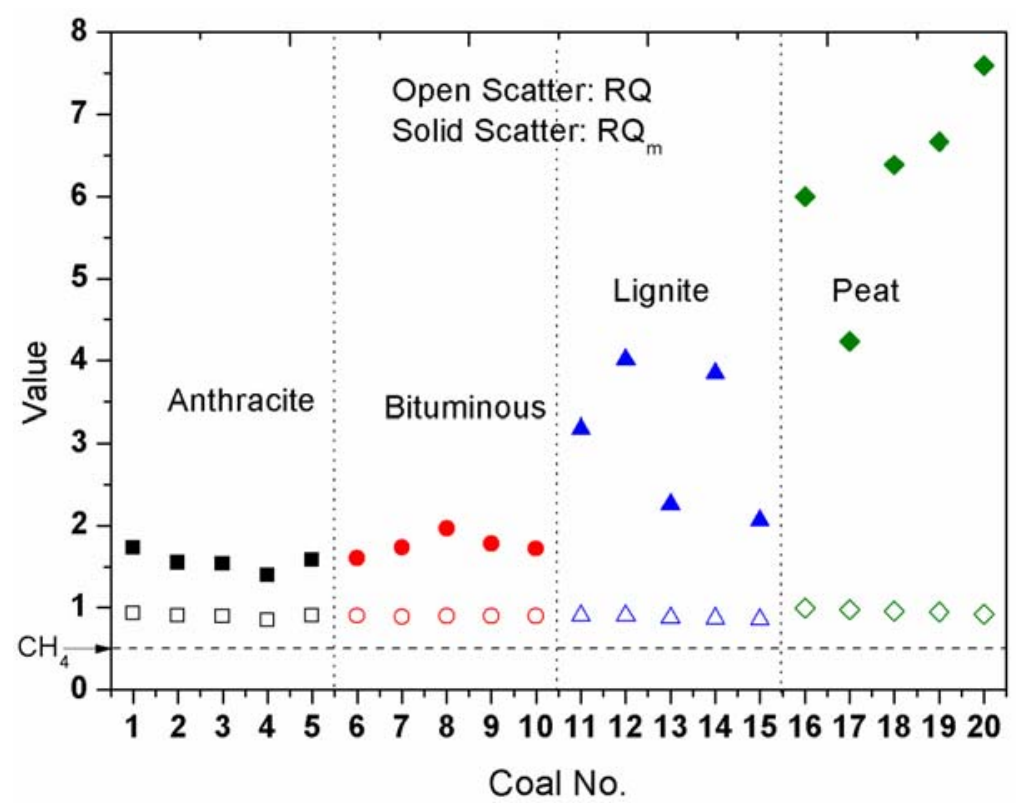

Figure $3 \mathrm{HHV}_{\mathrm{ad}}$ and $\mathrm{RQ}_{\mathrm{m}}$ of the four ranks of coals (see online version for colours)

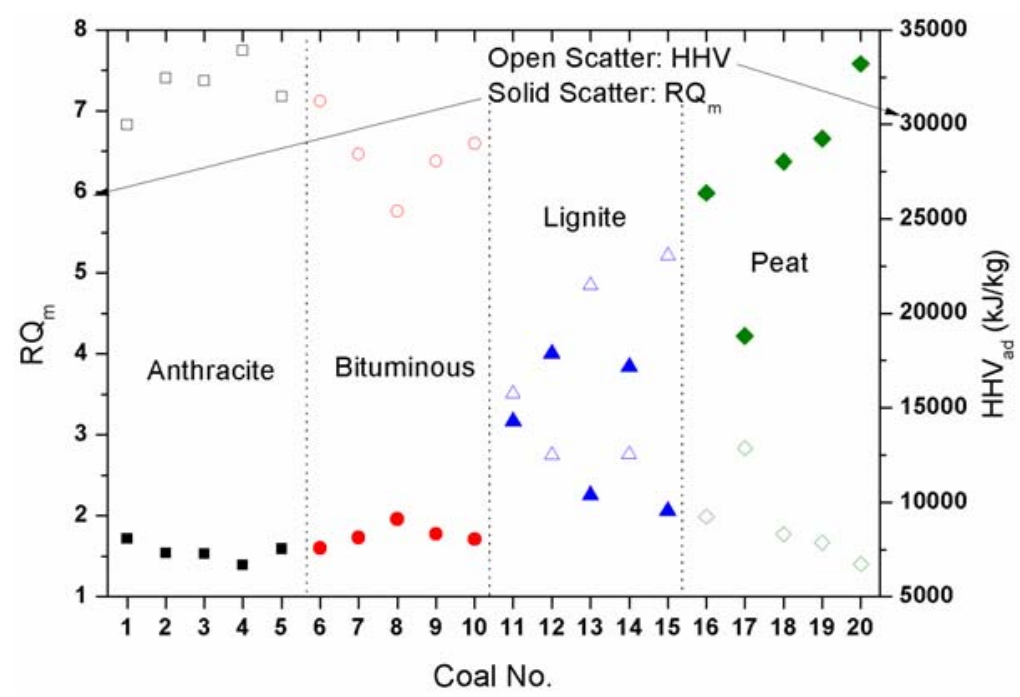

\section{$4.5 \mathrm{CO}_{2}$ emission}

The global warming is attributed primarily to the increasing industrial $\mathrm{CO}_{2}$ emissions into earth's atmosphere, especially $\mathrm{CO}_{2}$ emission from coal combustion. Coals with high $\mathrm{RQ}_{\mathrm{m}}$ tend to release more $\mathrm{CO}_{2}$ than fuels with low $\mathrm{RQ}_{\mathrm{m}}$ such as ethanol. The $\mathrm{CO}_{2}$ emission in tons/GJ of energy input from the fuel was estimated based on chemical composition, as shown in equation (8) (Thanapal, 2014): 


$$
C O_{2} \text { in tons / GJ }=\frac{1 \times 44 \times 1000}{\left\{422270 \times\left(1+\frac{117385}{422270}\right) \times\left(\frac{H}{C}\right)-\left(\frac{117440}{422270}\right) \times\left(\frac{O}{C}\right)\right\}}
$$

The relationship between $\mathrm{CO}_{2}$ emission and $\mathrm{RQ}_{\mathrm{m}}$ of these 20 coals is given in Figure 4. It shows that the $\mathrm{CO}_{2}$ emissions of coal combustion decrease with the increase of $R Q_{m}$ values, which means low quality fuels has less $\mathrm{CO}_{2}$ emission from combustion of coal per unit mass.

Figure $4 \quad \mathrm{CO}_{2}$ emissions and $\mathrm{RQ}_{\mathrm{m}}$ of the four ranks of coals (see online version for colours)

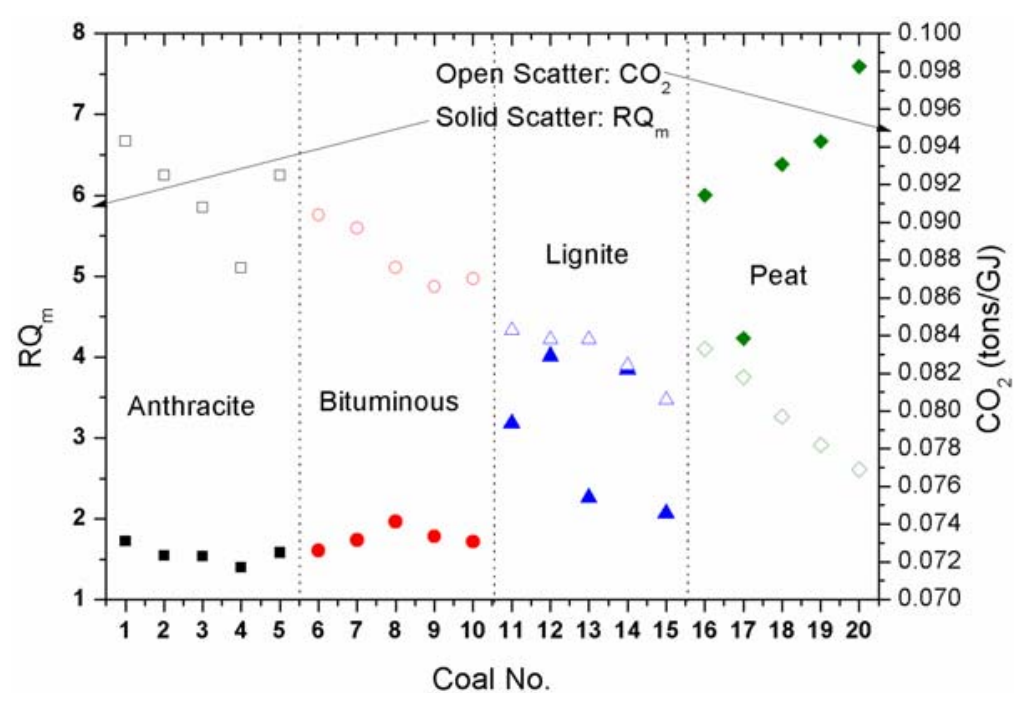

However, this trend does not reflect the actual $\mathrm{CO}_{2}$ emission of the coals since equation (8) does not take into account of the effect of moisture and ash on the combustion. High ash and moisture content of the coals not only decreases the heating values but also consumes more processing energy which results in more $\mathrm{CO}_{2}$ emission. Thus, equation (8) was further developed to estimate $\mathrm{CO}_{2}$ emission and the influence of processing low quality coals:

$$
C O_{2} \text { in tons / GJ }=h_{f} \frac{1 \times 44 \times 1000}{\left\{422270 \times\left(1+\frac{117385}{422270}\right) \times\left(\frac{H}{C}\right)-\left(\frac{117440}{422270}\right) \times\left(\frac{O}{C}\right)\right\}}
$$

where $h_{f}$ is the heating value factor. Based on equation (9), a new correlation between $\mathrm{CO}_{2}$ emission and $\mathrm{RQ}_{\mathrm{m}}$ is shown in Figure 5. It is found that $\mathrm{CO}_{2}$ emission is between 0.14 and 0.18 tons/GJ for anthracite and bituminous, while for low rank coals like lignite and peat $\mathrm{CO}_{2}$ emission goes up to around 0.5 tons/GJ. If the low rank coals were upgraded to high energy density fuels at a low energy penalty, $h_{f}$ would increase and $\mathrm{CO}_{2}$ emission would decrease. Recently, different technologies including conventional evaporation drying methods and non-evaporation dewatering methods such 
as mechanical thermal expression (MTE) process and hydrothermal dewatering (HTD) process were developed to remove moisture and increase the heating value of coals. Moreover, coals can also be blended with biomass to be burned in furnaces to reduce $\mathrm{CO}_{2}$ emission since biomass fuel is considered to be carbon neutral (Thanapal, 2014).

Figure 5 Modified $\mathrm{CO}_{2}$ emissions and $\mathrm{RQ}_{\mathrm{m}}$ of the four ranks of coals (see online version for colours)

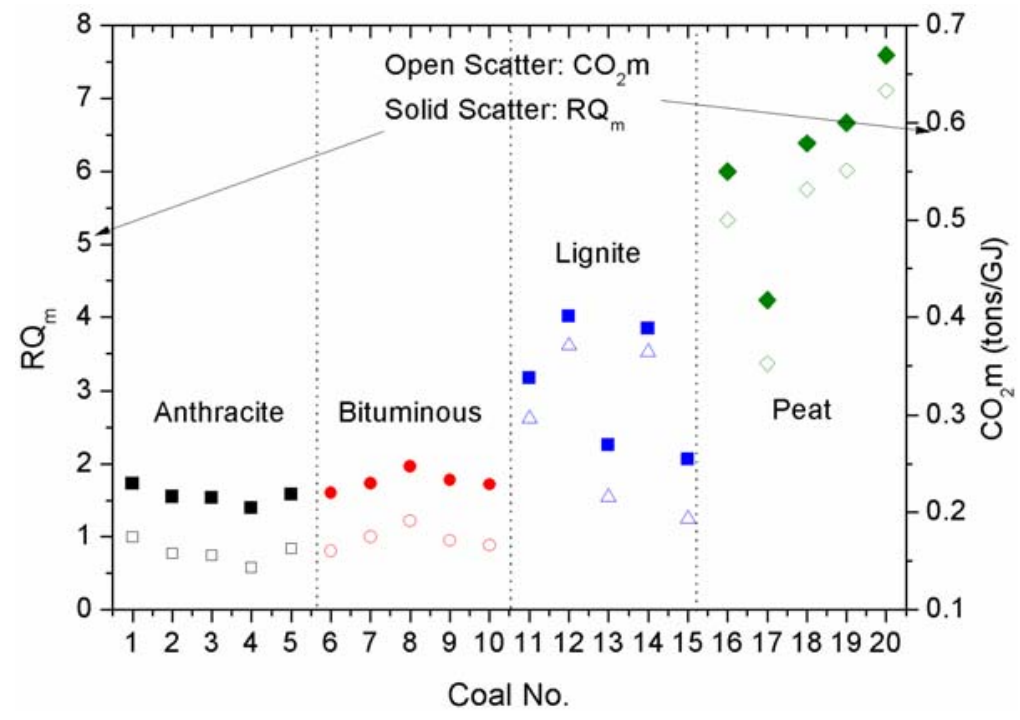

Figure 6 Variation of different coal $\mathrm{RQ}_{\mathrm{m}}$ with $\mathrm{O} / \mathrm{C}$ ratio (see online version for colours)

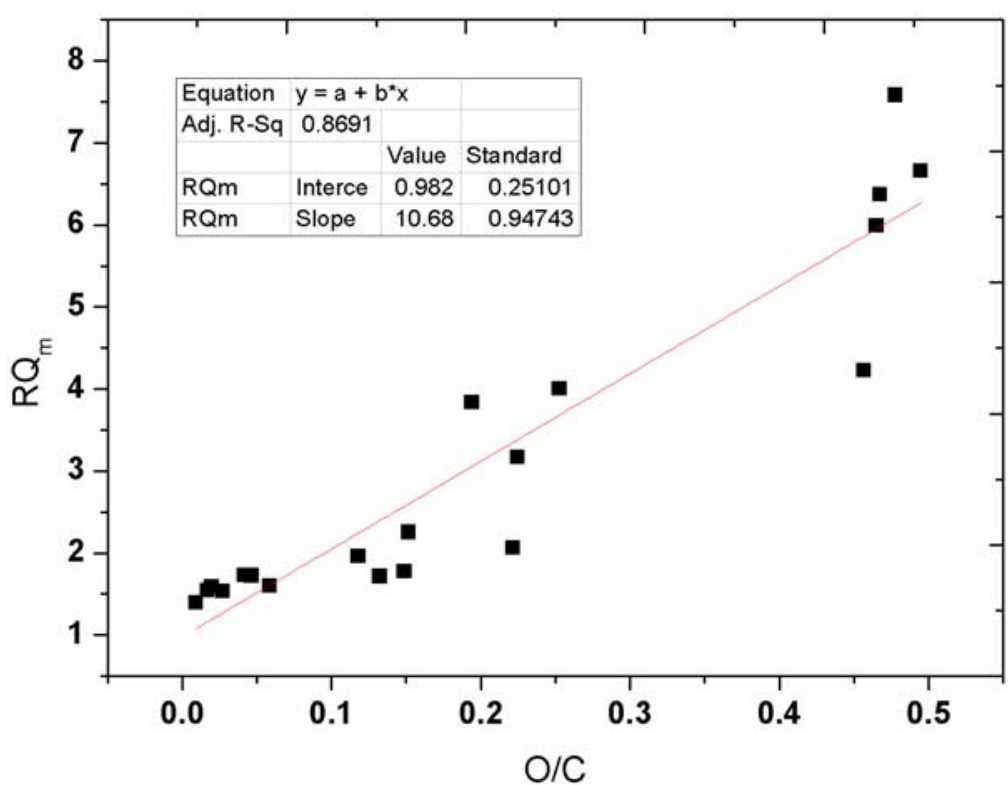




\section{6 $H / C$ and $O / C$ ratios $v s . R Q_{m}$}

Since solid fuels contain certain amount of moisture and ash which affect the $\mathrm{C}, \mathrm{H}$ and $\mathrm{O}$ elements in the fuels, $\mathrm{RQ}_{\mathrm{m}}$ shows strong correlation with $\mathrm{H} / \mathrm{C}$ and $\mathrm{O} / \mathrm{C}$ ratios. Thus, a linear relationship of $R Q_{m}$ and $O / C$ ratio $\left(R Q_{m}=10.680 / C+0.98\right)$ is plotted in Figure 6 . It can be seen from the equation that $\mathrm{RQ}_{\mathrm{m}}$ increases with an increase of $\mathrm{O} / \mathrm{C}$ ratio. The low-ranked coals like lignite contains high amount of oxygen. The oxidisation of the low ranked coals requires less oxygen and hence, results in increase of $R Q_{m}$ value.

Figure 7 Variation of different coal $\mathrm{RQ}_{\mathrm{m}}$ with $\mathrm{H} / \mathrm{C}$ ratio (see online version for colours)

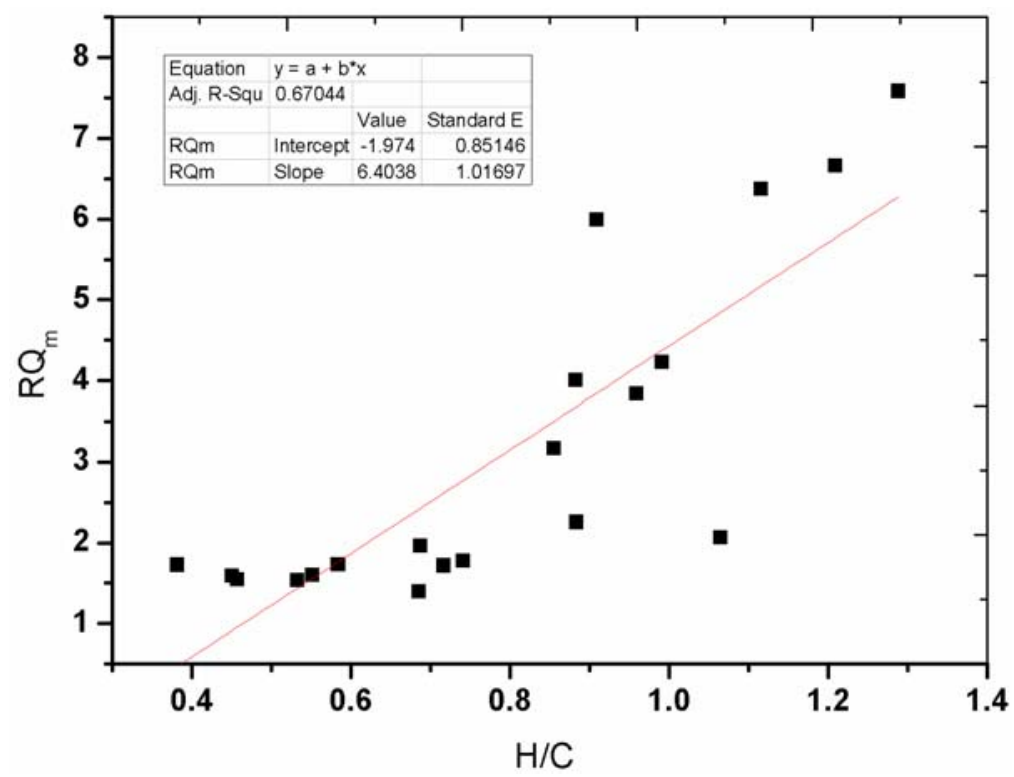

Figure 7 gives the relationship between $H / C$ ratio and $R Q_{m}\left(R Q_{m}=6.40 H / C-1.97\right)$. Similar to $\mathrm{O} / \mathrm{C}$ ratio, $\mathrm{H} / \mathrm{C}$ ratio increases with the decrease of coal quality. Moreover, $\mathrm{RQ}_{\mathrm{m}}$ increases with increase of $\mathrm{H} / \mathrm{C}$ ratio. Both oxygen and hydrogen contents increases with lowering of grade and decrease of energy density (e.g., low $h_{f}$ ).

\section{Zero RQ technology (zero emission)}

If $R Q_{m}$ is equal to zero, according to the definition of $R Q_{m}, C O_{2}$ emission from combustion should be zero which means the fuel has no GWP. Recently, various approaches for $\mathrm{CO}_{2}$ capture were studied. These approaches can be grouped into three categories: pre-combustion, oxy-combustion, and post-combustion (Smith et al., 2013). The post-combustion measures are the most popular method. For the post-combustion technologies, chemical loop combustion (CLC) is considered to be 'zero emission' 
technologies. $\mathrm{CO}_{2}$ is captured after combustion, which will be recycled and mixed with $\mathrm{O}_{2}$ as coal gasification agent. Thus, no $\mathrm{CO}_{2}$ is released to the atmosphere. These technologies reduce the $\mathrm{CO}_{2}$ emission and eventually reduce $\mathrm{RQ}_{\mathrm{m}}$. However, $\mathrm{CO}_{2}$ capture may cause considerable thermal efficiency penalties, typically varying from $6.5 \%$ to $15 \%$ (energy consumption for $\mathrm{CO}_{2}$ compression is included) depending on the technology pathways (Kanniche et al., 2010). Since any kind of energy consumption will result in $\mathrm{CO}_{2}$ emission, the actual $\mathrm{RQ}_{\mathrm{m}}$ of the $\mathrm{CO}_{2}$ capture would never be equal to 0 . The $\mathrm{RQ}_{\mathrm{m}}$ value for fuel production combined with $\mathrm{CO}_{2}$ capture will be studied in the near future.

\section{Conclusions}

In this study, RQ, a dimensionless index used in calculations of basal metabolic rate in the biological field, is modified to evaluate coal combustion and $\mathrm{CO}_{2}$ emission potential. The $\mathrm{RQ}_{\mathrm{m}}$, which considers the effect of ash and moisture content, is calculated to evaluate the $\mathrm{CO}_{2}$ emission potential of 20 coals. The results are listed below:

1 Generally, higher RQ value means higher $\mathrm{CO}_{2}$ emission during combustion. RQ of $\mathrm{CH}_{4}$ is 0.5 and RQ of coals are between 0.9 and 1 . The conventional RQ definition is based on dry and ash free basis hence it does not reflect the actual $\mathrm{CO}_{2}$ emission of coals.

2 Considering the effect of moisture and ash, high rank coals such as anthracite and bituminous have lower $\mathrm{RQ}_{\mathrm{m}}$ which ranges from 1 to 2 , while $\mathrm{RQ}_{\mathrm{m}}$ of peat is relatively high. It could go up to 7 . Higher $\mathrm{RQ}_{\mathrm{m}}$ (eg., low rank coal) means higher $\mathrm{CO}_{2}$ emission potential.

3 Lignite and peat have higher $\mathrm{O} / \mathrm{C}(>0.15)$ and $\mathrm{H} / \mathrm{C}$ ratios $(>0.85)$ than those of anthracite and bituminous. The heating values of the coals decrease with increase of $\mathrm{O} / \mathrm{C}$ ratio. Similar to heating value, $\mathrm{RQ}_{\mathrm{m}}$ also increase with increase of $\mathrm{O} / \mathrm{C}$ and $\mathrm{H} / \mathrm{C}$ ratios.

4 For zero emission technology, $\mathrm{RQ}_{\mathrm{m}}$ is zero since $\mathrm{CO}_{2}$ is captured after combustion. However, $\mathrm{CO}_{2}$ capture may decrease thermal conversion efficiency significantly and lead to increase of $\mathrm{RQ}_{\mathrm{m}}$. As a result, actual $\mathrm{RQ}_{\mathrm{m}}$ of hydrocarbon fuel combustion would not be zero. But with the advance of technologies, both $\mathrm{CO}_{2}$ emissions and $\mathrm{RQ}_{\mathrm{m}}$ of hydrocarbon fuel combustion would be very low.

\section{Acknowledgements}

The authors are grateful for funding supports of the National Natural Science Foundation of China (Nos. 51776132, 51406128) and the Natural Science Foundation of Jiangsu Province (Grant No. BK20140342). 


\section{Nomenclature}

\begin{tabular}{ll}
\hline Symbol & Description \\
\hline CLC & Chemical loop combustion \\
$\mathrm{CO}_{2}$ & Carbon dioxide \\
$\mathrm{h}_{\mathrm{f}}$ & Heating value factor \\
$\mathrm{HHV}$ & Higher heating value \\
$\mathrm{daf}$ & Dry and ash free basis \\
$\mathrm{ad}$ & As received basis \\
$\mathrm{HTD}$ & Hydrothermal dewatering \\
$\mathrm{MTE}$ & Mechanical thermal expression \\
$\mathrm{RQ}$ & Respiratory quotient \\
$\mathrm{RQ}$ & Modified respiratory quotient \\
\hline
\end{tabular}

\section{References}

Annamalai, K. (2013) 'Respiratory quotient (Rq), exhaust gas analyses, $\mathrm{CO}_{2}$ emission and applications in automobile engineering', Advances in Automobile Engineering, Vol. 2, No. 2, pp.1-3.

Annamalai, K., Sweeten J. and Ramalingam, S.C. (1987) 'Estimation of the gross heating values of biomass fuels', Trans. ASAE, Vol. 30, No. 4, pp.1205-1208.

Cheng, W., Gong, X.Z. and Guo, Z.C. (2015) 'Effects of oxygen concentration on combustion reactivity of pulverized coal and graphite catalyzed by $\mathrm{K}_{2} \mathrm{CO}_{3}$ ', The Chinese Journal of Process Engineering, in Chinese, Vol. 151, No. 1, pp.74-78.

DOE/EIA (1993) Emissions of Greenhouse Gases in the United States 1985-1990, September, Vol. DOE/EIA-0573 ed., p.16, Washington, DC.

EIA (2014) Total Carbon Dioxide Emissions from the Consumption of Energy 2014 [online] https:/www.eia.gov/cfapps/ipdbproject/IEDIndex3.cfm?tid=90\&pid=44\&aid=8 (accessed 11 January, 2017).

EIA (2017) International Energy Outlook 2017 [online] http://www.eia.gov/forecasts/ieo/coal.cfm (accessed 11 January, 2017).

Ge, H., Shen, L., Gu, H., Song, T. and Jiang, S. (2015a) 'Combustion performance and sodium transformation of high-sodium Zhundong coal during chemical looping combustion with hematite as oxygen carrier', Fuel, Vol. 159, pp.107-117.

Ge, H.J., Shen, L.H., Gu, H.M. and Jiang, S.X. (2015b) 'Effect of co-precipitation and impregnation on $\mathrm{K}$-decorated $\mathrm{Fe}_{2} \mathrm{O}_{3} / \mathrm{Al}_{2} \mathrm{O}_{3}$ oxygen carrier in chemical looping combustion of bituminous coal', Chemical Engineering Journal, Vol. 262, pp.1065-1076.

Gordillo, G., Annamalai, K. and Carlin, N. (2009) 'Adiabatic fixed-bed gasification of coal, dairy biomass, and feedlot biomass using an air-steam mixture as an oxidizing agent', Renewable Energy, Vol. 34, No. 12, pp.2789-2797.

Guo, Q.Q., Yang, Z. and Zhang, J.W. (2008) 'Property test and research on XiLinHaoTe lignite coal', Boiler Technology, in Chinese, Vol. 39, No. 57, pp.45-51.

Hong, B.D. and Slatick, E.R. (1994) 'Carbon dioxide emission factors for coal', Energy Information Administration, Quarterly Coal Report, Vol. DOE/EIA-0121, No. 94/Q1, pp.1-8.

Jangam, S.V., Karthikeyan, M. and Mujumdar, A.S. (2011) 'A critical assessment of industrial coal drying technologies: role of energy, emissions, risk and sustainability', Drying Technology, Vol. 29, No. 4, pp.395-340. 
Jiang, X.M. (1991) 'Techno-economic analysis and development and utilization of the peat energy sources in Jilin Province', Energy of China, in Chinese, No. 7, pp.12-14.

Kanniche, M., Gros-Bonnivard, R., Jaud, P., Valle-Marcos, J., Amann, J-M. and Bouallou, C. (2010) 'Pre-combustion, post-combustion and oxy-combustion in thermal power plant for $\mathrm{CO}_{2}$ capture', Applied Thermal Engineering, Vol. 30, No. 1, pp.53-62.

Li, G.Y., Wang, C.A., Yan, Y., Jin, X., Liu, Y.H. and Che, D.F. (2016) 'Release and transformation of sodium during combustion of Zhundong coals', Journal of the Energy Institute, Vol. 89, pp.48-55.

Li, Z., Guo, Z., Gong, X. and Tang, H. (2013) 'Kinetic characteristics of pulverized coal combustion in the two-phase flow', Energy, Vol. 55, pp.585-593.

Liu, J., Gao, S., Jiang, X., Shen, J. and Zhang, H. (2014) 'NO emission characteristics of superfine pulverized coal combustion in the $\mathrm{O}_{2} / \mathrm{CO}_{2}$ atmosphere', Energy Conversion and Management, Vol. 77, pp.349-355.

Ouyang, Z.Q., Zhu, J.G., Lu, Q.G., Yao, Y. and Liu, J.Z. (2014) 'Experimental study on combustion and NOx emission of pulverized anthracite coal preheated by a circulating fluidized bed', Proceedings of the CSEE, Vol. 34, pp.1748-1754, in Chinese.

Smith, N., Miller, G., Aandi, I., Gadsden, R. and Davison, J. (2013) 'Performance and costs of $\mathrm{CO}_{2}$ capture at gas fired power plants', Energy Procedia, Vol. 37, pp.2443-2452.

Thanapal, S.S. (2014) Effect of Co-Firing Torrefied Woody Biomass with Coal in a $30 \mathrm{kWt}$ Downfired Burner, PhD Dissertation, Mechanical Engineering, Texas A\&M University.

Thanapal, S.S., Eseltine D., Annamalai, K. and Ranjan, D. (2014) 'Biomass fuel quality enhancement and respiratory quotient (RQ) for ranking fossil and biomass fuels based on $\mathrm{CO}_{2}$ emissions', Novel Combustion Concepts for Sustainable Energy Development, pp.45-73, Springer India.

Yang, J.C., Sun, R., Sun, S.Z., Zhao, N.B., Hao, N., Chen, H. et al. (2015) 'Experimental study on NOx reduction from staging combustion of high volatile pulverized coals. Part 2. Fuel staging', Fuel Processing Technology, Vol. 138, pp.445-454.

Zou, C., Wen, L.Y., Zhang, S.F., Bai, C.G. and Yin, G.L. (2014) 'Evaluation of catalytic combustion of pulverized coal for use in pulverized coal injection (PCI) and its influence on properties of unburnt chars', Fuel Processing Technology, Vol. 119, pp.136-145. 